\title{
PEMBUATAN DAN KARAKTERISASI BIOPLASTIK BERBAHAN DASAR PATI UMBI UWI UNGU, PLASTICIZER GLISEROL DAN KITOSAN
}

\author{
Ahmad Albar, Rahmaniah*, Ihsan \\ Jurusan Fisika \\ Fakultas Sains dan Teknologi UIN Alauddin Makassar \\ Jl. Sultan Alauddin No. 63, Gowa, Sulawesi Selatan. 92113 \\ *E-mail: rahmaniah.fisika@uin-alauddin.ac.id
}

\begin{abstract}
Abstrak: Bioplastik merupakan alternatif pengganti plastik komersial yang dapat merusak lingkungan. Bioplastik dibuat untuk mempermudah degradasi. Salah satu bahan yang potensial adalah ubi ungu karena memiliki komponen pati yang paling tinggi. Penelitian ini bertujuan untuk mempelajari kualitas film bioplastik dari pati ubi ungu (Dioscorea alata) dengan dan tanpa penambahan kitosan, dan gliserol sebagai plasticizer terhadap sifat mekanik (uji kuat tarik, elongasi dan ketahanan air). Hasil yang diperoleh dengan variasi kitosan $0 \%$ dan 3\%, nilai kuat tarik terbesar diperoleh dengan konsentrasi kitosan 0\% (tanpa penambahan kitosan) sebesar 1,5369 $\mathrm{MPa}$, nilai persentase elongasi pada kitosan 3\% yaitu 14,50 \% dan nilai ketahanan air maksimum pada konsentrasi kitosan $0 \%$ yaitu $91,57 \%$. Dimana hasil yang diperoleh mendekati standar yang ada.
\end{abstract}

Kata Kunci: bioplastik, kitosan, gliserol, stratch, ubi ungu

\section{PENDAHULUAN}

$\mathbf{P}$ ermasalahan akan sampah plastik sintetis menjadi permasalahan yang cukup banyak menyita perhatian akhir-akhir ini. Penggunaan plastik yang meningkat seiring dengan peningkatan populasi manusia tidak seimbang dengan penanganan akan sampah yang dihasilkan, sehingga dampak negatif yang ditimbulkan juga sangat banyak, diantaranya yaitu plastik sintetis sangat berpotensi untuk mencemari lingkungan. Hal ini dikarenakan plastik sintetis susah dalam proses penguraiannnya di alam. Selain itu plastik ketika dibakar akan menghasilkan zat-zat yang berbahaya bagi kesehatan manusia dimana asap-asap yang dihasilkan mengandung gas-gas beracun seperti HCN (Hydrogen cyanide) dan CO (Carbon Monoxide) sehingga berdampak pada pencemaran udara dan menimbulkan efek jangka panjang seperti pemanasan global (Borghei, 2010), selain itu menurut Gong (2015), peningkatan yang cukup drastis pada produksi sampah plastik berimbas pada masalah serius yang ditimbulkannya seperti polusi lingkungan dimana polusi terhadap lingkungan yang dihasilkan dari sampah plastik berasal dari bahan dasar pembuatan plastik ini yaitu bahan bakar fosil yang dalam proses penguraiannya di alam membutuhkan waktu yang cukup lama sehingga sampah plastik ini memiliki julukan white pollution atau polutan putih (asap). Maka dari itu diperlukan langkah yang tepat untuk mengatasi permasalahan tersebut, berbagai penelitian telah dilakukan salah satu dan yang paling gencar dan dianggap paling menjanjikan untuk dilakukan adalah dengan pembuatan bioplastik.

Bioplastik merupakan plastik yang dapat digunakan seperti plastik konvensional yang memanfaatkan bahan baku dasar yang tersedia di alam seperti pati, minyak nabati, 
dan mikrobiota sehingga dapat diurai oleh mikroorganisme dalam waktu yang singkat dan dapat didaur ulang, karena alasan tersebut bioplastik termasuk dalam plastik ramah lingkungan, dalam pembuatan bioplastik setidaknya dibutuhkan tiga komponen utama yaitu pati, plasticizer dan kitosan. Pati merupakan salah satu polimer alam yang paling banyak tersedia di alam dan mempunyai sifat yang mudah terurai, sifat mekanis yang baik serta cukup terjangkau dari sisi ekonomis, karena alasan inilah polimer alam jenis pati ini banyak diteliti dan dikembangkan untuk menghasilkan plastik yang ramah lingkungan untuk mengganti plastik sintetis yang digunakan saat ini. Namun pati yang umumnya bersifat hidrofilik sangat memengaruhi stabilitas dan sifat mekanik dari biodegradable film yang dihasilkan sehingga ketahanan plastik terhadap air rendah dan mudah hancur, oleh karena itu untuk meningkatkan nilai fisisk dan fungsional dari biodegradable film ini diperlukan penambahan bahan yang mampu mengatasi kelemahannya ini, yaitu kitosan yang berfungsi untuk memperbaiki kekuatan lembar biodegradable film yang dihasilkan dan plasticizer berupa gliserol atau Virgin Coconut Oil (VCO) yang berfungsi untuk meningkatkan fleksibilitas pada film (lembaran biodegradable film), menghindari film dari keretakan, meningkatkan elastisitas film serta menjaga ketahanan film dari uap air maupun gas (Nahwi, 2016).

Menurut Standar Nasional Indonesia (SNI) Bioplastik yang baik adalah bioplastik yang mempunyai karakteristik yang mendekati plastik konvensional hal tersebut dapat kita dilihat pada Tabel 1.

Tabel 1. Standar Nasional Indonesia tentang bioplastik

\begin{tabular}{ll}
\hline Karakteristik & Standar \\
\hline Kuat tarik & $24,7-302 \mathrm{MPa}$ \\
Persen perpanjangan & $21-220 \%$ \\
Ketahanan terhadap air & $99 \%$ \\
\hline
\end{tabular}

Selain dengan menggunakan SNI, kualitas bioplastik film yang baik yaitu memenuhi standar moderate propertiesi yaitu standard bioplastik film untuk kemasan. Adapun nilainya yaitu untuk kuat tarik sebesar 10-100 MPa dan untuk persen elongasinya yaitu pada kisaran 10-20\% (Purwanti, 2020).

Penelitian tentang pembuatan bioplastik ini sudah cukup banyak dilakukan dengan menggunakan pati dari berbagai jenis tumbuh-tumbuhan namun belum mencapai nilai yang maksimal, maka dari itu pada penelitian ini menggunakan pati dari umbi uwi ungu (Dioscorea alata) hal ini dikarenakan kandungan pati yang terdapat dalam uwi ungu ini cukup tinggi yaitu sekitar 86,13\% dalam setiap 100 gram daging uwi ungu (Winarti, 2013), selain itu pemanfaatan dari uwi ini masih terbilang rendah padahal potensi hidupnya cukup tinggi di daerah tropis seperti Indonesia.

\section{METODE PENELITIAN}

Alat yang digunakan pada penelitian ini yaitu FTIR (Fourier Transform-Infra Red), mesin kuat tarik (mechanical universal testing machine), alat inkubasi, neraca analitik, magnetic stirrer, hotplate, alat pengukur ketebalan (micrometer scrup), blender, cetakan flexi glass berukuran $20 \times 20 \mathrm{~cm}$, gelas ukur $100 \mathrm{ml}$, gelas kimia $250 \mathrm{ml}$, gelas kimia 500 $\mathrm{ml}$, batang pengaduk, lumpang dan alu, termometer $100^{\circ} \mathrm{C}$, pipet skala $1 \mathrm{ml}$, pipet skala $10 \mathrm{~mL}$, pembakar bunsen, ayakan, labu takar $1000 \mathrm{ml}$, spatula dan gunting. Sedangkan bahan-bahan yang digunakan adalah aluminium foil, asam asetat $\left(\mathrm{CH}_{3} \mathrm{COOH}\right) 1 \%$, larutan natrium metabisulfit $0,75 \%$, gliserol, aquades $\left(\mathrm{H}_{2} \mathrm{O}\right)$, kertas saring, kitosan, spiritus, pati umbi uwi dan tisu. 
Langkah-langkah yang dilakukan pada penelitian ini meliputi:

1. Pembuatan Pati

Mula-mula umbi uwi dikupas untuk memisahkan antara daging dengan kulit. Daging yang telah diperoleh kemudian dipotong kecil-kecil kemudian dicampurkan dengan larutan natirum metabisulfit $0,75 \%$ dengan perbandingan 1:2, setelah dicampurkan dengan larutan natrium metabisulfit daging umbi kemudian diblender selama satu menit yang bertujuan untuk menghancurkan dinding sel agar granula pati keluar dari jaringan umbi, bubur yang dihasilkan kemudian diperas dengan sarung peras untuk memisahkan antara pati dengan ampasnya. Setelah itu hasil perasan diendapkan selama 24 jam dengan menggunakan gelas kimia $1000 \mathrm{ml}$, pati akan mengendap di dasar gelas kimia. Pati yang dihasilkan kemudian dikeringkan di bawah terik matahari sampai kering total kemudian dihaluskan menggunakan lumpang dan alu kemudian diayak menggunakan ayakan untuk mendapatkan bubuk pati.

2. Pembuatan Larutan Natrium Metabisulfit $\left(\mathrm{Na}_{2} \mathrm{~S}_{2} \mathrm{O}_{5}\right) \quad 0,75 \%$

Natrium Metabisulfit 0,75\% sebanyak 0,75 gram ditimbang menggunakan neraca digital kemudian dimasukkan ke dalam gelas ukur dan ditambahkan dengan 99,25 ml aquades dan dihomogenkan menggunakan magnetic stirrer pada suhu $40^{\circ} \mathrm{C}$ selama 25 menit.

3. Pembuatan Larutan Pati

Larutan pati dibuat dengan cara menimbang pati daging umbi uwi sebanyak 5 gram dilarutkan dalam $100 \mathrm{ml}$ aquades di dalam gelas kimia, kemudian diaduk menggunakan magnetic strirer selama 25 menit dengan cara pemanasan di atas hot plate pada suhu $80^{\circ} \mathrm{C}$ sampai terbentuk larutan homogen.

4. Pembuatan Larutan Kitosan 3\%

Larutan kitosan 3\% dibuat dengan cara menimbang sebanyak 3 gram kitosan dan dimasukkan ke dalam gelas piala $250 \mathrm{ml}$. Selanjutnya dilarutkan dalam asam asetat $1 \%$ sampai volume $100 \mathrm{ml}$, kemudian diaduk menggunakan magnetic stirrer selama 25 menit dengan cara pemanasan di atas hot plate pada suhu $80^{\circ} \mathrm{C}$, karena magnetic stirrer berhenti secara otomatis maka dilanjutkan dengan pengadukan secara manual menggunakan bantuan pembakar bunsen dan diaduk menggunakan batang pengaduk sampai campuran homogen dan mengental.

5. Pembuatan Larutan Biodegradable Film

Pembuatan larutan biodegradable film, dilakukan dengan cara mencampurkan larutan pati 5\% (larutan yang dibuat pada prosedur 3) dengan larutan kitosan 3\% (larutan yang dibuat pada prosedur 4). Kemudian ditambahkan larutan gliserol sebanyak $25 \%$ dari berat pati ke dalam larutan pati-kitosan yaitu sebanyak $1,25 \mathrm{ml}$. Setelah itu, larutan dihomogenkan menggunakan magnetic stirrer pada suhu $80^{\circ} \mathrm{C}$ dengan putaran $600 \mathrm{rpm}$, karena magnetic stirrer berhenti secara otomatis maka dilanjutkan dengan pengadukan secara manual menggunakan bantuan pembakar bunsen dan diaduk menggunakan batang pengaduk sampai campuran dirasa homogen dan mengental.

6. Pencetakan Bioplastik

Campuran film dituang ke dalam cetakan kaca berukuran $20 \mathrm{~cm}$ x $20 \mathrm{~cm}$. Selanjutnya dikeringkan menggunakan inkubator dengan selama 24 jam. Setelah itu cetakan dikeluarkan dari oven dan didinginkan dalam suhu kamar. Film yang terbentuk dikelupas dari cetakan kemudian disimpan dalam wadah kedap udara. Lembaran yang dihasilkan kemudian dipotong dengan ukuran $3 \mathrm{~cm}$ x $5 \mathrm{~cm}$. Lembaran film selanjutnya diuji karakteristiknya yang meliputi, uji kuat tarik, persen pemanjangan dan uji daya serap. 


\section{HASIL DAN PEMBAHASAN}

Hasil dari penelitian yang dilakukan menunjukan bahwa biodegradable film dengan penambahan kitosan akan memengaruhi karakteristik biodegradable yang dihasilkan. Adapun biodegradable yang terbentuk pada masing-masing penambahan kitosan dapat dilihat pada Gambar 1.

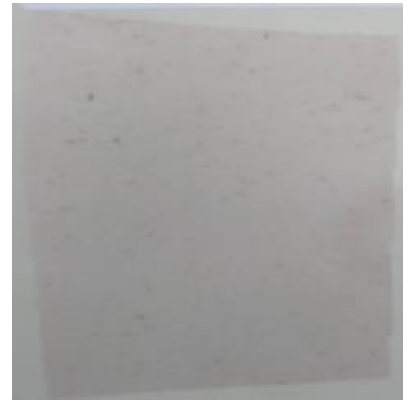

Gambar 1. Perbandingan biodegradable film: (a)Tanpa Penambahan Kitosan dan (b) Dengan penambahan kitosan $3 \%$

Penampakan fisik bioplastik tanpa penambahan kitosan memiliki warna yang jernih dan halus sedangkan pada bioplastik dengan penambahan kitosan memiliki warna yang agak kecoklatan dan memiliki permukaan yang agak kasar disertai dengan gelembunggelembung kecil pada permukaannya (Gambar 1).

Kemampuan kuat tarik yang diperoleh dari biodegradable yang diuji cukup rendah, dan belum memenuhi SNI, hal ini tidak sesuai dengan teori dimana seharusnya dengan penambahan kitosan akan memengaruhi besar kuat tarik, karena fungsi dari kitosan dalam pembuatan biodegradable adalah sebagai penguat, namun terlihat pada hasil uji yang ada penambahan kitosan malah mengurangi kemampuan kuat tarik biodegradable, penurunan kuat tarik dengan penambahan kitosan disebabkan oleh pencampuran bahan-bahan yang kurang homogen, seperti terlihat pada Gambar 1, permukaan biodegradable dengan penambahan kitosan cukup kasar dan terdapat gelembung-gelembung, sehingga ikatan antar molekul-molekul cukup renggang, sehingga biodegradable pada saat pengujian cepat putus. Hal tersebut diperkuat dengan penelitian yang dilakukan oleh Simarmata et al. (2020) yang menyatakan bahwa ikatan yang terbentuk pada biodegradable seharusnya membentuk ikatan rantai cabang, anyaman dan struktur yang rapat sehingga menyebabkan kuat tarik semakin meningkat, namun pada pencampuran yang kurang homogen mengakibatkan distribusi komponen kurang merata sehingga material yang terbentuk mengalami penurunan kuat tarik.

Selain itu pada persen perpanjangan (elongasi) terlihat bahwa dengan penambahan kitosan kemampuan atau persen perpanjangan meningkat namun hasil yang didapatkan belum memenuhi SNI namun sudah memenuhi standard moderate properties untuk bioplastik kemasan (Tabel 2). Untuk ketahanan terhadap air pada penambahan kitosan malah lebih rendah tidak sesuai dengan teori dimana seharusnya dengan penambahan kitosan maka tingkat daya serap airnya menurun, namun terlihat bahwa bioplastik dengan penambahan kitosan terdapat gelembung-gelembung pada permukaan hal ini menyebabkan air mudah masuk ke dalam bioplastik, kemunculan gelembung-gelembung ini berasal dari homogenisasi atau pencampuran yang tidak sempurna sehingga menurunkan kualitas dari bioplastik itu sendiri. 
Tabel 2: Hasil analisis kualitas bioplastik uwi ungu (Diosccora alata)

\begin{tabular}{lccc}
\hline \multicolumn{1}{c}{ Parameter } & $\begin{array}{c}\text { Konsentrasi Kitosan } \\
(\%)\end{array}$ & Nilai Rata-Rata & Standar \\
\hline \multirow{2}{*}{ Kuat tarik (MPa) } & 0 & 1,5369 & $>24,7-302(\mathrm{MPa})$ \\
Persen pemanjangan (\%) & 3 & 0,2868 & $>21-220 \%$ \\
Ketahanan air $(\%)$ & 0 & 10,41 & \\
& 3 & 14,50 & $99 \%$ \\
\hline
\end{tabular}

\section{KESIMPULAN}

Dari penelitian ini didapatkan bahwa umbi uwi ungu (Dioscorea alata) memiliki potensi untuk dijadikan bahan dasar bioplastik dimana diperoleh hasil yang mendekati SNI tentang bioplastik dan untuk persen perpanjangan sendiri sudah memenuhi standard Moderate Properties sehingga memungkinkan untuk dijadikan plastik kemasan.

\section{DAFTAR PUSTAKA}

Borghei, M., A. Karbassi., S. Khoramnejadian., A. Oromiehie., \& A.H. Javid. (2010). Microbial biodegradable potato starch based low density polyethylene. African Journal of Biotechnology, 9(26), 4075-4080.

Gong, J., J. Liu., X. Chen, Z. Jiang., X. Wen., E. Mijowska., \& T. Tang. (2015). Converting real world mixed waste plastics into porous carbon nanosheet with excellent performance in adsorption of organic dye from wastewater. Journal of Materials Chemistry, 3, 341-351.

Nahwi, N.F. (2016). Analisis Penambahan Plasticizer Gliserol pada Karakteristik Edible Film dari Pati Kulit Pisang Raja, Tongkol Jagung dan Bonggol Enceng Gondok. [Skripsi]. Malang: Fakultas Sains dan Teknologi UIN Maulana Malik Ibrahim.

Purwanti, A. (2010). Analisis kuat tarik dan elongasi plastik kitosan terplastisasi sorbitol. Jurnal Teknologi, 3(2), 99-106.

Simarmata, E.O., A. Hartiati., \& B.A. Harsojuwono. (2020). Karakteristik komposit bioplastik dalam variasi rasio pati umbi talas (Xanthosoma sagittifolium)-Kitosan. Jurnal Ilmiah Teknologi Pertanian Agrotechno, 5(2), 75-80.

Winarti, S., \& E.A. Saputro. (2013). Karakteristik tepung prebiotik umbi uwi (Diascora spp.). Teknik Kimia, 8(1), 17-21. 